\title{
住宅誌による三世代同居家族の平面型の変遷に関する研究 A STUDY ON THE CHANGES IN PLANNING FOR THREE-GENERATION-FAMILY HOMES AS SEEN IN HOUSING MAGAZINES
}

\author{
本 間博文*, 砥 波 恵子** \\ Hirobumi HONMA and Keiko TONAMI
}

The aim of this study is to trace how housing for three-generation families has changed in the past half century and thereby to predict futures changes and obtain useful information for housing.

In order to make a successive analysis of the part changes, 1300 examples of housing plans for three-generation families have been selected from magazines published since pre-wart imes and analyzed according to each period.

The study has proven that the three-generation family characteristic of Japan will continue to exist and will continue to be the main type of family arrangements in Japan.

Keyword: three-generation-family,housing plan,housing magazine,past change of housing plan, type of housing life,

三世代同居家族、住宅平面、住宅誌、平面型の変遷、住生活の型

\section{1.はじめに}

わが国は、急激に高齢社会へ突入しつつあるが、それ にあわせて伝統的な家族形態も大きく変わりつつある。 核家族化による家族規模の縮小は、高龄者の扶養能力を 低下させる一方、家制度の崩罗が扶養意識に微妙な変化 を及ぼしている。年金の充実に伴う高齢者の所得水準の 上昇によって、高齢者自身の自立意識が高まっているこ とも、このような意識の変化を一層加速している。

しかし、親子それぞれの世带が同じ家に、あるいは同 じ敷地内に隣接して生活をする親子同居が、必ずしもこ のような変化に対応して急激に減少しているともいえな い。確かに国勢調査による高齢者世帯の動向を見ると、 高齢者夫婦だけの世帯あるいは高齢者単独世帯の比率が 増加し、子等と同居している家族の比率は低下している が、絶対数は減少していない。しかも、国勢調查では、 住居が上下、あるいは左右に隣接していても、それぞれ の住戸の独立性が高く、その上、生計を別にしている場 合は、親子別世帯として扱われてしまい、同居形態の実
態を反映していない面もある。住民票で、高齢者単独世 帯として扱われても、意識も、実態も、親子同居である と言った家族が相当数あることも報告されている。この ように今日の住宅の現状を考慮すると、三世代同居とい う居住形式は今後もわが国の主要な居住形態として存続 していくものと思われる。

しかし、高龄者の平均寿命の延びによって、ライフサ イクルも変質し、同居可能期間 ${ }^{\mathrm{i}}$ が長期にわたり、伝統 的な三世代同居とは異なった、多様な同居生活を展開し ているように思われる。加えて、わが国の高齢者の福祉 政策が在宅福祉に比重をおいている事情も含めて、高齢 期の家族生活、とりわけ子供の家族と同居している住生 活の実態を明らかにすることは、高齢者用住居だけの問 題にとどまらず、今後の住計画全般、あるいは住宅政策 に重要な示唆を与えることになるだろう。

このような視点から、高齢者とその子供の家族とが同 居している住空間が、どのように変化し、現在どのよう な空間を志向しているかを、明らかにする事を本研究の

* 放送大学教養学部 教授・工博

***放送大学教盖学部 学生

Prof., Faculty of Liberal Arts, The University of the Air, Dr. Eng. Under Graduate Student, Faculty of Liberal Arts, The University of the Air 
第一義的な目的とする。併せて、得られた資料を基に、 それらの空間の中で展開されている住生活の実態を、考 察しょうとするものである。

\section{2. 先行研究}

このような三世代同居家族を含む高齢者家族の住生活 に関する既往の研究はそれほど多くない。

松本暢子は「既成市街地の高齢者居住に関する研究」 において山の手、下町など典型的な三地域の住民票、現 地調査、土地. 家屋課税台帳調査、一部高齢者へのインタ ビューにより、土地、住宅の規模などの住宅状況が、高 齢者の家族型、居住形態に関係していることを明らかに している ${ }^{i i i}$ 。この論文は高龄者の住宅事情を明らかにし たもので、住生活については立ち入った論究が行われて いない。一方清水安子は住宅金融公庫申し込み住宅の平 面型の類型化とそれらの平面型に対応した住生活の関わ りを論じ、二世帯住宅の平面構成は、生活、経済面の関 わりが、共用スペースに反映されると報告しているiv。 清水の研究は住宅の平面型をもとに二世带住宅の住生活 の特徵を論じた興味深い論文ではあるが、1 時点での調 査で、しかも調査世帯も全国に散在している77 7ンプ ルの集計にとどまっており、得られた結論によって直ち にそれが二世帯住宅に共通してみられる特性であるとす るにはやや資料が不足しているように思われる。

上記の報告以外にも高龄者の住宅、住生活に関する報 告がいくつか見られるが、高齢者同居家族の住空間と住 生活との関連を論じたものはほとんど見られない。

そこで、筆者らは、三世代同居家族の住宅における一 日の生活行動を、一定時間ごとに何処の部屋で、誰が、 何をしているかを調へ、その資料をもとに家族関係を詳 細に分析した。その結果、同居家族は、各世代がそれぞ れ一体となって生活をしている型（交流型）と親子二家 族が、比較的独立性の高い生活を営んでいる家族（分離 型）と、世代を問わず、それぞれの専有空間（個室）に 分かれてしまう型（分散型）の三つの主要な生活の型が あることを明らかにしだ、。

この結果を受けて、生活時間調査を簡略化し、対象サ ンプル增やした調查を、1992 年度に実施し、その結 果、親子二世帯の空間の分離と生活の分離とが、ほぼ対 応関係にあることを、1993 年度の建筑学会大会に報 告した ${ }^{\mathrm{vi}}$ 。こういった生活時間調查は、家族生活の内面 に迫ることが出来るので、有効な研究手法ではあるが、 信頼性については議論のあるところでもあり、何らかの 他の方法によって得られた資料と突き合わせながら、さ らに詳細に検討する必要がある。

一方、今日、多様なライフスタイルが混在しており、 まして高龄者と子供の家族との同居となると、一層複雑
な居住形態が予想される。将来どのように変化していく のか、その動向を予測し得るような研究も必要である。 そのためには、過去から現在に至る生活の変化を捉える 研究も必要となるだろう。

\section{3. 研究方法}

このような点を鑑み、本研究は中高齢者を含む三世代 同居住宅の居住形態の推移を、住宅誌に掲載された新筑 住宅の平面図を元に分析し、その変化していく過程と、 それぞれの時点における典型的な同居の型を明らかにし ようと試みたものである。住宅誌に掲載された新築住宅 の大半は、住み手が、対価を支払って設計を依頼し、何 度かの打ち合わせを繰り返し、設計を進め、工事管理を 行って、出来上がった住宅である。住宅誌で取り上げら れるだけの技量を持った設計者が、施主と密度の濃い打 ち合わせを繰り返し、施主の家族の様々な住要求を汲み 上げ、調整し、空間に具体化したものと考えられる。そ の住宅が、同居を行うにふさわしいものであると、住み 手が納得した上で、実現した住まいである。

つまり、住宅誌に掲載された住宅は、新筑時点での、 住み手の家族生活の空間的表現と考光、誌面に揭載され た住宅を分析することによって、その時々の住み手の生 活要求、住要求を検証することが可能と考える。

もとより、資料上の制約はあるが、前述の生活時間調 查など、他の研究方法によって得られた資料と詳細に内 容を突き合わせて検討し、より信頼性の高い結論を得る ことも可能である。

ところで、住宅誌に掲載された新築住宅を研究の対象 として取り上げるにあたって、いくつか、問題もある。 これらの住宅は、わが国の一般的住宅の水準に比べて、 より経済的に恵まれた層の住宅である。また雑誌毎の固 有の編集方針に基づいて選定されたもので、その時々の 標準的サンプルと考えて良いかも問題である。

こう言った制約があるものの、上記のような性格の住 宅が、大量にしかも時系列に沿って収集できるという点 で、重要な研究資料であると確信し、本研究では住宅誌 に揭載された住宅の平面を分析の対象として取り上げる こととする。

「三世代同居」について、本研究では、同居を同一敷 地に建筑された住居であり、その親子の住宅形態が別棟 でも、上下あるいは水平に分離した形態であるうと、親 子の同居と考元、同居形態が変化したものであるとの見 解の元に今回の分析の対象に組み入れた。表面的な交流 がないにしても、気配を感じあえる状態は、コミュニケ ーションの重要な要件と考えるからである。さらに、親 子二夫婦同居住宅も今回の分析対象とした。

参照した住宅誌は、次の 2 誌である。住宅誌「朗」 
表 1 対象サンプル数

\begin{tabular}{|c|c|c|c|c|c|c|c|}
\hline 期閩 & $\begin{array}{l}\text { 昭和 } 1 \\
0 \text { 年代 }\end{array}$ & $\begin{array}{l}\text { 昭和 } 2 \\
0 \text { 年代 }\end{array}$ & $\begin{array}{l}\text { 昭和 } 3 \\
0 \text { 年代 }\end{array}$ & $\begin{array}{l}\text { 昭和 } 4 \\
0 \text { 年代 }\end{array}$ & \begin{tabular}{|l} 
昭和 5 \\
0年代
\end{tabular} & $\begin{array}{l}\text { 昭和 } 6 \\
0 \text { 年代 }\end{array}$ & 合旪 \\
\hline 䏝名 & O期 & I 期 & II 期 & 四期 & IV期 & $\mathrm{v}$ 期 & VI⿰H \\
\hline 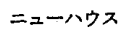 & 15 & 0 & 60 & 279 & 211 & 310 & 874 \\
\hline モダンリヒン & 0 & 29 & 65 & 95 & 79 & 99 & 365 \\
\hline 合影 & 15 & 29 & 125 & 379 & 289 & 409 & 123 \\
\hline
\end{tabular}

(昭和20〜30年まで休刊) は、昭和37年より「ニューハ ウス（以後NHと略す）」と誌名が変更されているが、 この住宅誌の昭和 11 年より平成 4 年まで。もう一誌は、昭 和 26 年より平成 4 年までの「モダンリビング（以後ML と略す）」である。この 2 誌に掲載された、三世代同居 住宅 1239 例を抽出し、掲載順に誌上に記載された事 項をデータベース化し、同居形態の類型化を試みた。こ の間の推移を明らかにするため、戦前を 0 期とし、戦後 の昭和 20 年代から平成 4 年までを、10年毎に I 期より V 期にわけ分析を行なった（表 1）。

\section{4. 調査対象の特性}

4. 1 対象地区

調査のために取り上げた住宅は、全て戸建て住宅であ る。対象サンプルは、日本全国に及んでおり、その内、 東京地区が35\%を占めており、関東地区が全体の $2 / 3$ 以上を占める。「ニューハウス」に比べ「モダンリビン グ」は関東地区の比率が $77 \%$ と高くなっている。雑誌に よる編集方針によるものと思われる（表 2）。

表 2 対象住宅の地域分布

\begin{tabular}{|c|c|c|c|c|c|c|c|c|c|c|}
\hline & $\begin{array}{l}\text { 北海 } \\
\text { 道 }\end{array}$ & 東北 & 関東 & $\begin{array}{l}\text { 北陸 } \\
\text { 隹越 }\end{array}$ & 東海 & 闦西 & 中国 & 四国 & 九州 & 合計 \\
\hline$E=x-n b^{2}$ & 19 & 31 & 548 & 17 & 82 & 69 & 29 & 21 & 17 & 833 \\
\hline 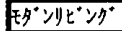 & 0 & 1 & 147 & 3 & 10 & 23 & 2 & ( & $\mathrm{l}$ & $\begin{array}{ll}188 \\
\end{array}$ \\
\hline 計 & 19 & 32 & 695 & 20 & 92 & 92 & 31 & 22 & 18 & 1021 \\
\hline
\end{tabular}

4. 2 二誌の編集方針と対象住宅の性格

両誌の編集方針は、「家を建てる人への情報提供一ニ ューハウス編集部談」と「快適な住まいとインテリアを 追求するーモダンリビング編集部談」とその限りではそ れほど違いが認められない。しかし、「ニューハウス」 の方は、「一般の読者を対象とする」、としており、意 匠的に独特のカラーを持った作品は少ない。設計者の選 定も、従来のつながりを重視し、掲載希望があれば考慮 するとのことで、特に斬新なデザインであることを重視 していない。

それに対し、「モダンリビング」の方は、インテリア を重視していることからも理解できるように、デザイン 志向がより鮮明である。住宅にこだわりを持っている読 表 3 二誌の比較

\begin{tabular}{|c|c|c|c|c|c|c|}
\hline & 刘象数 & \begin{tabular}{c|} 
平均家族 \\
人数
\end{tabular} & $\begin{array}{c}\text { 平均教地 } \\
\text { 面称 }\end{array}$ & $\begin{array}{c}\text { 平坋延- } \\
\text { 面程 } \\
\end{array}$ & 平均室数 & 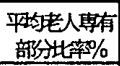 \\
\hline$E \rightarrow v^{2} x$ & 799 & 5.1 & 333.7 & 174.3 & 6.8 & 16.9 \\
\hline$E^{\prime \prime} \cup 11^{*} \cup \pi^{*}$ & 272 & 5.2 & 379.5 & 185.5 & 6.8 & 17.9 \\
\hline
\end{tabular}

者、あるいはインテリアの勉強をしている学生などを対 象とした誌面構成である。従って、作家的な意識の強い 設計者の作品を扱う傾向が強く、編集部が積極的に新し い設計者を発掘する努力も行っている。

当然、両誌の扱う住宅は、それぞれ固有の傾向が認め られるものと思われた。しかし、昭和 40 年代から、昭 和 60 年代までの両誌の対象住宅の面積、室数、老人の 占有領域などの平均值を比較したが（表 3）、その限り ではとりわけ顕著な違いが認められなかった。そこで以 後の分析は、両誌の資料を合計したものを使用する。

\section{2 家族規模と構成}

厚生省の行政基礎調査による平均世帯人員は、昭和 30 年が 4.68 人であり、昭和 55 年には3. 31 人と世帯が細分化 され核家族化が進んでいることが認められる。本調査で は三世代家族ということもあり、家族人員も多く、戦前 は5.5人であるが、戦後は 5 人程度で推移している。家族 人数には同居人も含まれ、0 期は同居人のいる家庭が 46. $5 \%$ でその比率は高く、III期では11\%と徐々に減少傾向を

表 4 家族型の分類

\begin{tabular}{|c|c|c|}
\hline 分類 & 区分 & 家族型 \\
\hline \multirow{4}{*}{ A } & 1 & 親世代夫婦、子世代夫嬠 \\
\hline & 2 & 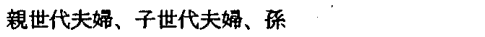 \\
\hline & 3 & 親世代夫嬠、子世代の兄弟姉妹、子世代夫婦 \\
\hline & 4 & 親世代夫姃、子世代の兄弟姉妹、子世代夫婷、棌 \\
\hline \multirow{4}{*}{ B } & 1 & 親世代単身、子世代夫䎄 \\
\hline & 2 & 親世代単身、子世代夫婦、係 \\
\hline & 3 & 親世代単身、子世代の兄弟姉妹、子世代夫婦 \\
\hline & 4 & 親世代単身、子世代の兄弟姉妹、子世代夫娪、孫 \\
\hline \multicolumn{2}{|l|}{$\mathrm{C}$} & その他 \\
\hline
\end{tabular}

示し、IV期以後は殆ど含まれていない。これを考慮にい れると家族数は 5 人前後で推移しており、あまり変化は認 められない。尚、親世代人数は戦前加ら次第に増加して いる。家族構成については、同居家族に特定し、住宅誌 に掲載された時点での家族構成を表 4に示した 9 パター ンに細分化し、分析した。

家族の年齢については原資料にほとんど揭載されてい ないので、分析の対象とすることができなかった。従っ て本調査では同居する親の年齢を 65 才以上の高齢者と限

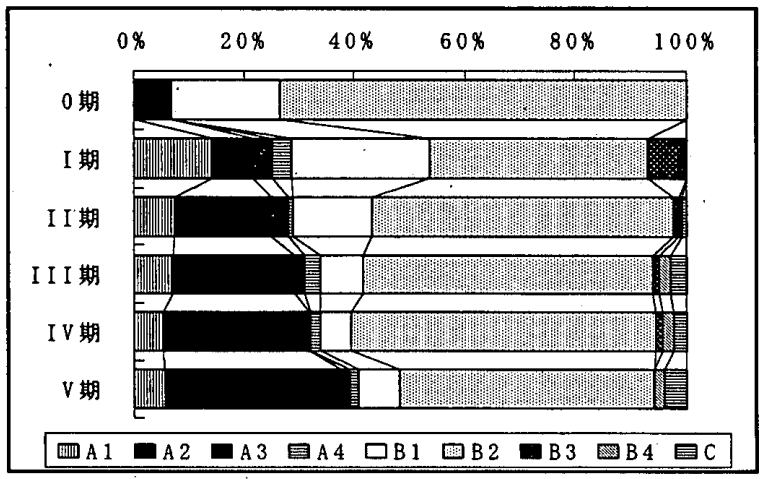

図 1 家族型の推移 
定出来ず、親の年齢が65歳以下ということもあり得る。 なお、以後、本論文中で、各世代をそれぞれ親世代：子 世代、孫世代と称する。

親世代で、両親健在の場合をAグループ、単身の場合 はBグループ、その他の家族構成をCグループとした。全 体的には $80 \%$ \%が一般的な三世代家族である。内 $4 \%$ 弱は子 世代夫婦の兄弟姉妹も含む。親世代が夫婦の場合 $27 \%$ 、 単身の場合が54.7\%である。二世代つまり孫のいない家 族も $17 \%$ を占め、高い值を示している。このような家族 型の時系列の推移を前頁图 1に示す。単身親の三世代同 居が、0期は90\%以上を占め、I 期〜IV期は60\%以上で、 $\mathrm{V}$ 期は55\%でやや比率が減少する一方、親世代の夫婦が 揃っている家族の比率が増加している。

4.3 家屋構造及び階数、規模

全事例の 7 割が木造建築である。鉄筋コンクリートは 2 割弱を占める。0期から I 期までは殆どが木造建築で
占められており、II 期以降は木造が70\%台で推移し、鉄 筋コンクリート、鉄骨及び混構造の住宅が増えている。

建物階数は全体的には 2 階屋が $82.7 \%$ 占め、3 階以 上は7. $4 \%$ である。0期、I 期は平屋建てが半数を占めて いたが、II期以降は多層階が増加している。家屋構造及 ひ敷地面積との関連が深いと思われる。

親世代の居住階は 1 階居住が $83 \%$ \%部分を占めるが、 II期以降 2 階居住も少しずつ増加しており、1 階と 2 階 の両方使用という居住形態も見られるようになる。

敷地面積は 0 期より 而期まで徐々に広くなっているが、 而期をピークに以後狭少化する。住宅統計調査のそれぞ れの調査年度における、戸建て平均敷地面積に比へてて規 模が大きい。延床面積は I 期が終戦直後という特殊事情 を考慮すると、年次別に搪大していく傾向が認められる。 住宅着工統計と比較しても三世代住宅ということもあり、 かなりゆとりのある住宅である。

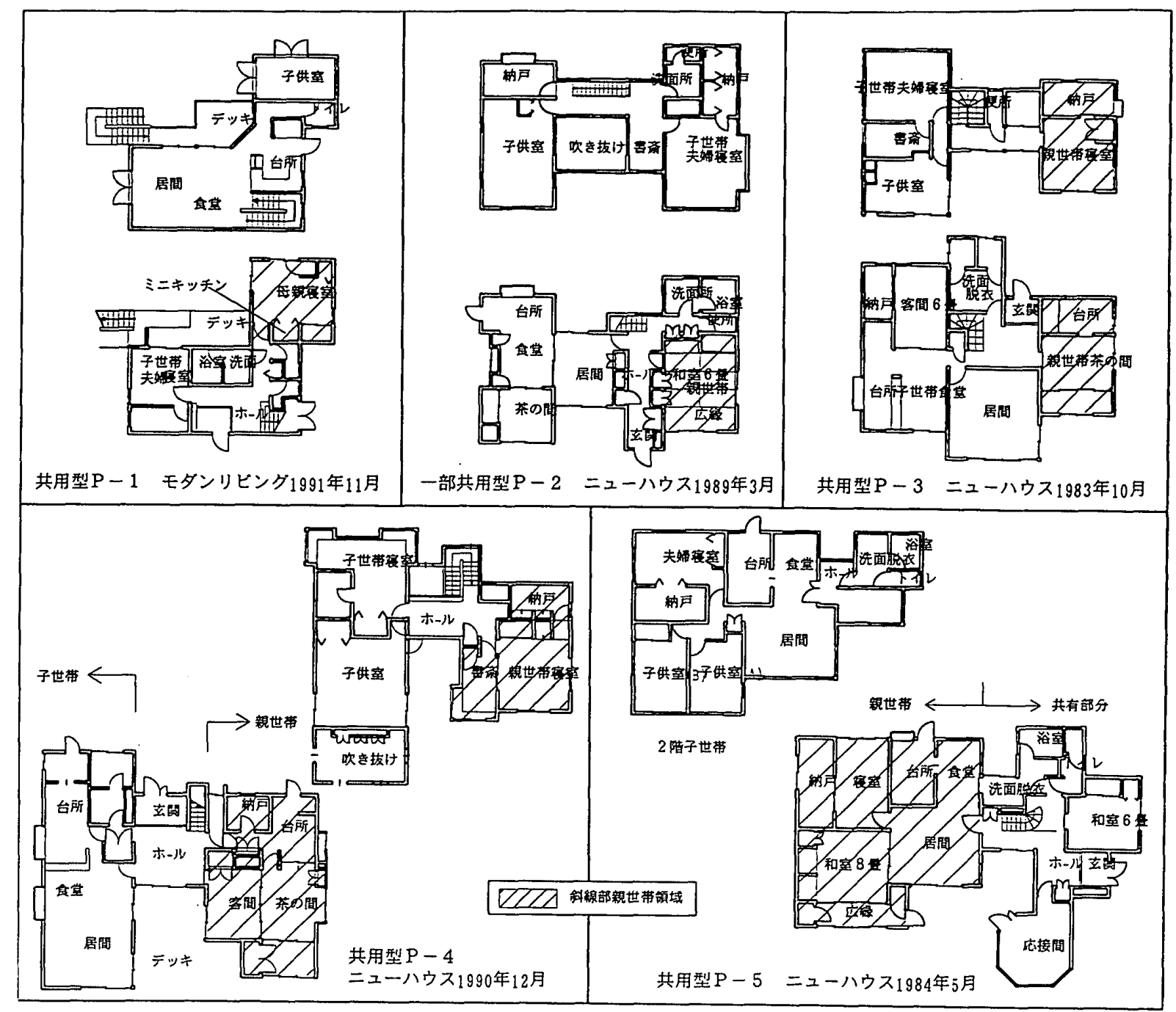

図 2 平面図 -1 


\section{5 同居形態}

5. 1 同居形態の類型化

どのような同居形態を選択するかは、親世代、子世代 の生活様式や家族の価値観に強く影響される。当然地域 間の差も大きく、各世代の独立性はそれぞれの年齢、健 康状態、収入に左右されると同時に、住宅条件としての 敷地面積、住宅の延床面積、居室数などにも規定される。 同居形態の時系列毎の変化を本論では、住宅の平面図を もとに分析を行った。とりわけ、世代間の独立度を判定 する指標として、台所と玄関に着目し、共有の度合いや 動線を元に同居の型分けを行った（表 5）。

(1)一体型 : 従来から存在する親世代、子世代の個室 以外すべて一緒に生活する型

（2）共用型：共用型は親子それぞれの領域に専用の台 所（ミニキッチンを含む）があるかどうかにより判別し た。その他、台所だけに限らず、その他の空間も含めて
表 5 同居形態のパターン

\begin{tabular}{|c|c|c|}
\hline 分類 & 内釈 & 内容 \\
\hline 一体型 & & 親世帯居室のみ専用 \\
\hline & 二部供用型P1 & 親世代サブキッチン \\
\hline & 二部供用型 $\mathrm{P} 2$ & 子世代サブキッチン \\
\hline \multirow[t]{5}{*}{.巷用.型 } & 一部供用型 P3 & 玄関，浴室、蜜室共用 \\
\hline & 一部共用型P4 & 玄関、浴室共用 \\
\hline & 一部供用型P 5 & 客室共用 \\
\hline & 一部供用型P 6 & 浴室共用 \\
\hline & 上下分醀 & 同一建物、上下分踓 \\
\hline \multirow{2}{*}{..分.雕.型 } & 左右分矍 & 同一建物、 \\
\hline & 灌九型 & 国 一慗地、別 㨂 \\
\hline
\end{tabular}

生活の一部を分離、一部を共用する平面型である。生活 上どの部分を共用しているのか、共用形態により一体型 に近いパターンから分離型に近いパターンまで、共用パ ターンをさらにP1〜P6に類別分類した。

（3）分離型：親世代、子世代の空間が分離した平面型 である。この型には戦前からの隠居形式で認められる離 れ型（別棟）、同一棟を左右にわけて居住する左右分離

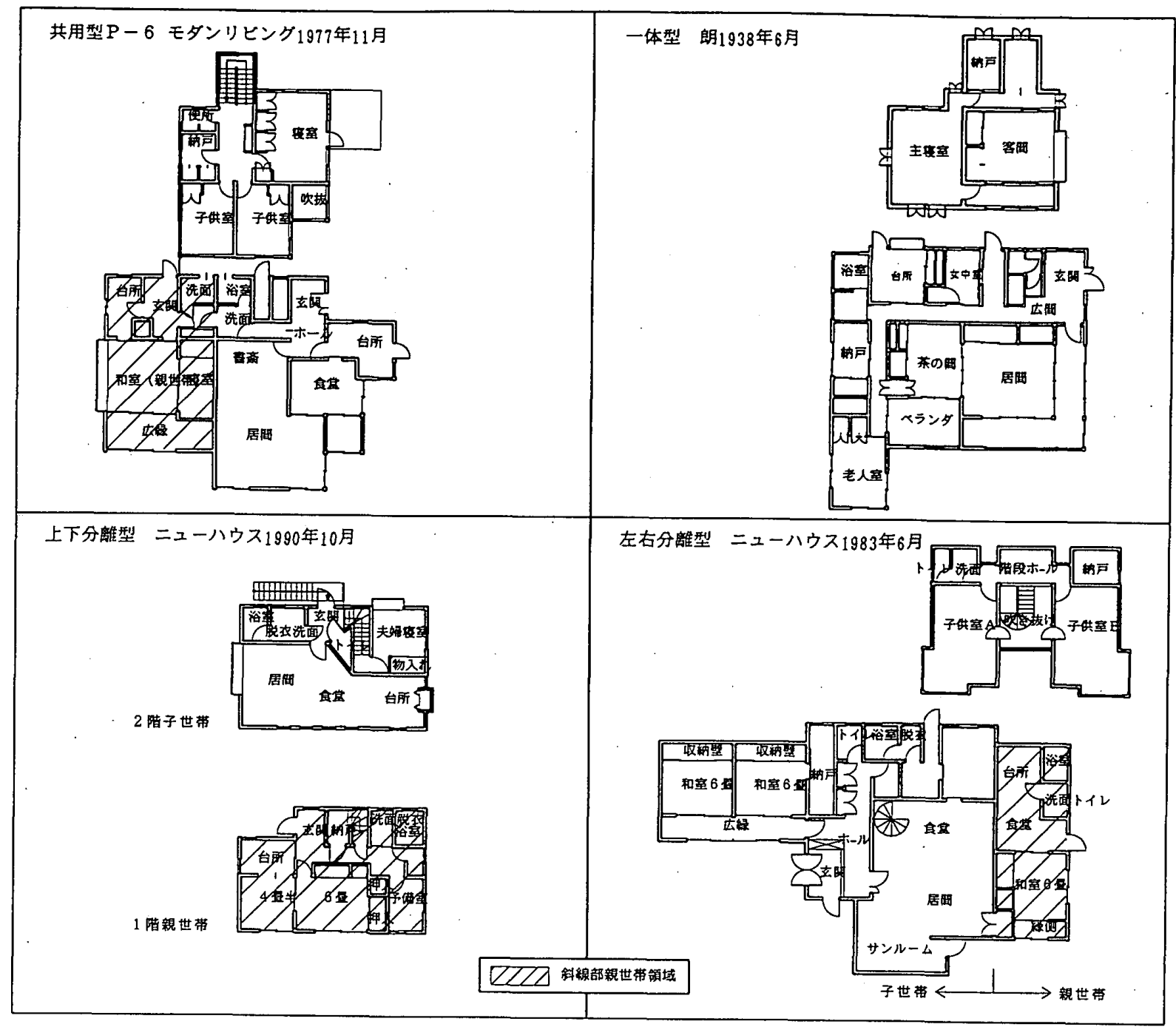

図 3 平面図 -2 


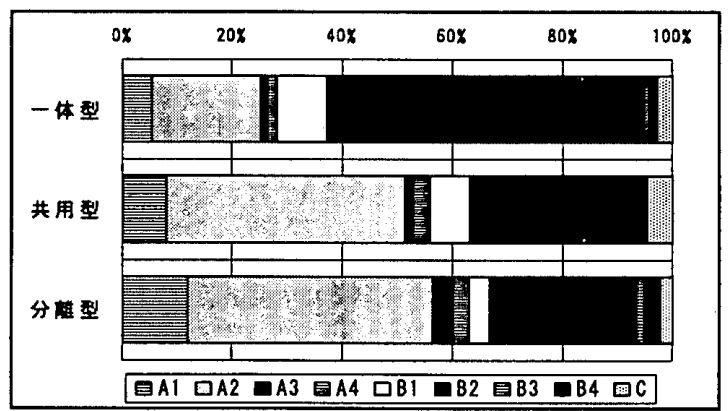

図 4 同居形態別家族構成

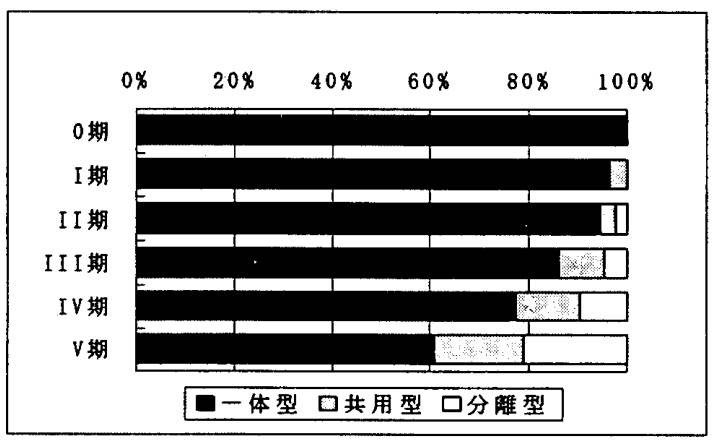

図 5 同居型の推移

型、上下にわかれて居住する上下分離型が認められた。 上下分離型の中には、玄関だけを共有し、その他の生活 を完全に分離している事例も含めた。税法上の特典加ら、 このような平面型を志向する傾向がある点を考慮したた めである。この型は20例見られた。3つの型のそれぞれ の典型事例を図 2 と図 3に示す。

\section{2 同居形態別家族構成}

図 4は、それぞれの同居形態別家族型である。一体型 では親世代で夫婦が揃っている場合の同居が $28 \%$ 、単身 の親との同居が $69 \%$ である。共用型は親世代が夫婦の場 合の同居が $56 \%$ 、単身の親との同居が $39 \%$ であり、分離 型では親世代が夫婦の場合の同居が $63 \%$ 、単身の親との 同居が $35 \%$ を占める。分離型では両親との同居の比率が 高く、一体型では片親との同居傾向が強い。年齢が比較 的若く、両親がそろっており、元気なあいだは別れて生 活する傾向にあることが認められる。家族構成における 親世代の状況が、同居形態を決定する一要因になると考 えられる。

\section{3 同居形態の推移}

同居形態の推移を図 5に示す。全体としては一体型が $76.8 \%$ 、共用型 $12.2 \%$ 、分離型 $11.0 \%$ を占める。前述し たように0期は「朗」のみ、I 期は「モダンリビング」 のみの集計である。0期、I 期はサンプルが少ないが、 大部分が一体型である。II期以降共用型、分離型が現わ れ、正期以降その比率も増加の傾向を示し、居住形態と しては分離傾向へ移行していく傾向が顕著に認められる。 しかし、V期でも依然60\%が一体型である。

5.3 .1 共用される空間
共用型は I 期に 1 例みられる。この事例では親子が左 右に分離し、中央部分に台所と浴室を共用している。こ の事例のようにそれぞれ専有の立関を持ち、台所を共用 する形態は特殊で、全事例中この 1 例のみであった。II 期は事例数は少ないが共用型では浴室を共用する型の比 率が高い。 III期以降になると共用パターンは多様化する。

P1は親世代の領域にサブキッツチン、P2は子世代の領 域にサブキッチン所有の形態である。生活の便宜上すぐ 近くでお湯が沸かせたり、調理できる台所を所有する型 は、生活を分離する観点からは最初の段階といえるが、 同時に大きなL. D. K. で団らんを共有するという型は、一 体型に近い形態といえる。P1とP2の合計は、III期 $35 \%$ 、 $\mathrm{IV}$ 期 $31.5 \%$ 、V 期 $42.7 \%$ と推移している。親世代、子世 代のどちらにサブキッチンを設置するかは、それぞれの 年代と生活主体をどこに置くのかにより決定されると思 われる。どの期でも親世代にサブキッチン所有の率が高 い。共用パターンではP4の玄関、浴室共用の型の占める 比率が高く、III期 $35.3 \% 、 \mathrm{IV}$ 期 $52.6 \% 、 \mathrm{~V}$ 期 $41.3 \%$ の高 率で推移している（図 6）。浴室のみ共用の形態は減少 しており、客室のみ共用はIV期よりみられるようになり、 V期に増加している。

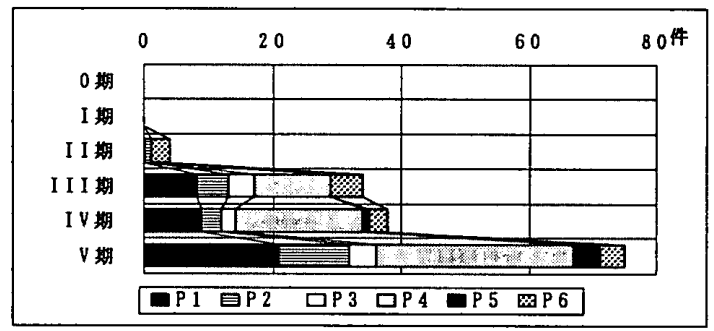

図 6 共用パターンの推移

\section{3 .2 分離型の推移}

分離形態では、上下分離型の事例が一番多く、67.7\% を占め、左右分離型 $21.3 \%$ 、離れ型は $11 \%$ である。時系 列では、離れ型の比率は堿少傾向にある。左右分離型は 事例数では増加している。上下分離型は確実に事例数が 増え、特にV期に急増している。完全分離の形態をとる 事例は、分離型の $43.4 \%$ を占め、残りの $56.6 \%$ は分離型 であっても階段やドアを介して内部で連絡が可能な形態 をとっている。この傾向は特にV期に強くなり、この型 だけで分離型全体の半分以上を占めるようになる。普段 の日常生活は別でも、どこかでつながりを持っていたい という意向が窅え、今後分離型の主要な平面型になるも

\begin{tabular}{|c|c|c|c|c|}
\hline 分離 & II 期 & III & IV & V期 \\
\hline $\begin{array}{l}\text { 上下分㒕 } \\
\text { 内内部行き来可 }\end{array}$ & & $\begin{array}{r}12(66.7) \\
8(44.4) \\
\end{array}$ & $\begin{array}{l}17(60.7) \\
10(35.3) \\
\end{array}$ & $\begin{array}{l}63(73.3) \\
44(51.2)\end{array}$ \\
\hline $\begin{array}{l}\text { 左右分䧸 } \\
\text { 内，内部行き来可 }\end{array}$ & & $\begin{array}{l}2(11.1) \\
2(11.1) \\
\end{array}$ & $\begin{array}{l}8(28.6) \\
2(7.1) \\
\end{array}$ & $\begin{array}{l}18(20.9) \\
10(11.6)\end{array}$ \\
\hline 雄九型 & $3(100)$ & $4(22.2)$ & $3(10.7)$ & $5(5.8)$ \\
\hline 合計 & 3 & 18 & 28 & 86 \\
\hline
\end{tabular}


のと思われる（表 6）。

5.4 同居形態別住宅規模の推移

各期とも同居形態別の敷地面積は一体型が広い傾向を 示している。ある程度以上の敷地面積が確保されれば、 敷地面積が同居形態を決定する要因とはならないようで ある。

延床面積は、同居形態別に、一体型、共用型、分離型 の順に広くなる。居住の分離化は、居室以外の台所、浴 室、玄関などの複数化を伴い、確実に延床面積の拡大に 結びついていることを反映している

居室数は、I 期の平均4.5室を除いて、分離型は8室前 後で推移し、一体型は6〜7窒の間で推移している。一体 型と分離型では1〜1.5室居室数の差が認められ、共用型 はこの中間で推移する（図 7)。

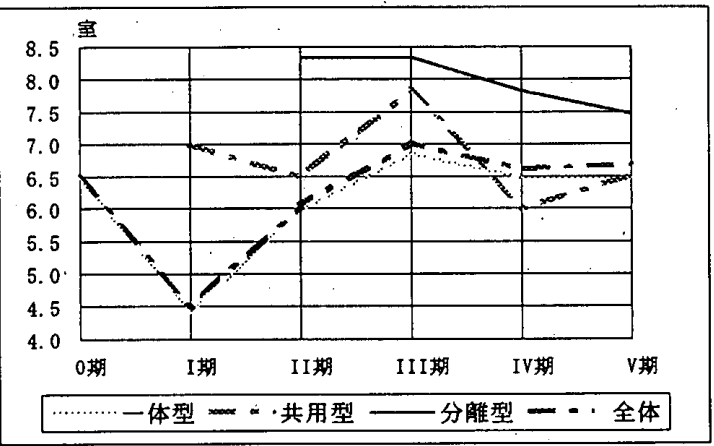

図 7 全居室数の推移

\section{6 親世代の居住実態}

6. 1 親世代の専有面積

親世代の専有面積として、居室及び、明らかに親世代 の領域にあると考えられる部分を算出した。その結果、 親世代の専有面積は、同居形態によって明らかな差が認 められた。共用型は一体型の2倍以上、分離型は3倍以上 の面積になっている。一体型では、0期の専有面積は13 $\mathrm{m}^{2}$ であり、I 期を除いてV期の平均 $20 \mathrm{~m}^{2}$ と少しずつ広くな っている。しかし、延床面積に対する占有比率は0期が $10.8 \% 、 V$ 期が $12 \%$ でありその占める割合にあまり変化 は見られない。共用型における専有面積はやや分散が大 きいが、26〜 49 m゙推移し、延床面積に対する比率は I

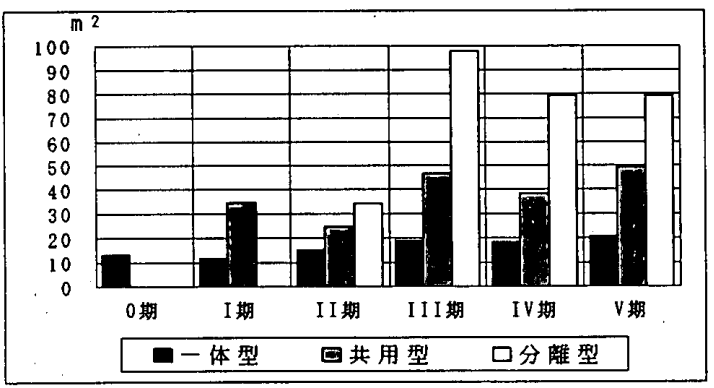

図 8 親世代居住面積の推移
期は36\%と高いが、II期以降は22〜26\%で推移している。 分離型が現われる I期における、分離型の親世代の専有 面積は34 $\mathrm{m}^{2} て ゙ 、$ III期以降専有面積は急上昇し、98〜 $79 \mathrm{~m}^{2}$ と推移している。延床面積に対する比率は、III期は43. $7 \%$ で以後37 38\%を占める。生活の分離傾向が強くなる と、親世代の専有面積が増加し、その占有比率も高くな るという当然の結果が得られた。

一体型が $10 \%$ 強、共用型はばらつきが多いが、大体 $20 \%$ 強、分離型で30数\%程度が、親世代の専有部分が延 べ面積に占める割合と言えそうである（图 8）。

\section{2 親世代用居室数}

一体型では 1 室のみが $81.4 \%$ で大部分を占め、2 室以 上が19.6\%である。共用型は 1 室 $31.6 \% 、 2$ 室 $39.5 \%$ 、 3 室以上が $29 \%$ で 2 室の割合がやや高い。分離型は 2 室2 $7.4 \% 、 3$ 室 $38.5 \% 、 4$ 室以上 $30.4 \%$ となり、親世代の居 室も分離度が高まるにつれてその数が増える傾向が顕著 に認められる。年次別の推移を見ると、一体型は 1 室を 中心に推移し 2 室専有も少しずつ増加している。複数室 では続き間の形式が多くなっている。共用型は 2 室中心 に推移、 1 室、 2 室、 3 室と 3 分化して推移している。 共用形態により室数に差が生じるものと思われる。分離 型は 3 室中心に推移している。

\section{7 一体型の居住実態}

同居形態の年次別の推移でも明らかなように、分離傾 向が顕著に認められるとはいえ、依然として一体型の比 率は高く、V期でも $60 \%$ 占めている。伝統的な同居形態 であるが、その内容にどのような変化が認められるか、 と言った点を明らかにするため、一体型の親世代の専有 する空閒がどのような領域に属しているか、またその領 域にどのような経路によって到達するかという2 点から 分析を行った。

7.1 親世代の占有空間が属する㴿域

住宅の平面は基本的に、公室領域と私室領域に分けら れる。これをもとに、親世代の居室の領域を大別して4 類型に分けた（表 7）。全体的には、独立領域型 $52.3 \%$ 、 公室領域接続型 $32.8 \%$ 、他の私室と同領域にある型 $13 \%$ 、 公私室同領域型1.9\%である。II期以降は独立領域型は52 〜 55\%、公室領域接続型は29～36\%の間を推移し、この

表 7 一体型の居室領域

\begin{tabular}{|c|c|}
\hline 型 & 内容 \\
\hline 独立領域型 (0) & $\begin{array}{l}\text { 親世代の居室が独立した領 } \\
\text { 域に存在している型 }\end{array}$ \\
\hline 公室頖域接続型 (LO) & $\begin{array}{l}\text { 親世代の扂室が公室に接䌇 } \\
\text { ている型 }\end{array}$ \\
\hline 私室領域接続型 (P) & $\begin{array}{l}\text { 他の私室々同領域または接 } \\
\text { 続している型 }\end{array}$ \\
\hline 公私空同項域型 & $\begin{array}{l}\text { 公室、私室、顛世代居室驾 } \\
\text { 同一領域に存在している型 }\end{array}$ \\
\hline
\end{tabular}




\begin{tabular}{|c|c|c|c|c|c|}
\hline & $20 \%$ & $40 \%$ & $60 \%$ & $80 \%$ & \\
\hline 0期 & 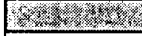 & (3.2. & & & \\
\hline 1 期 & 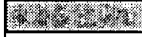 & & & & \\
\hline II 期 & 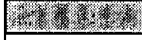 & 4 & & & \\
\hline III期 & 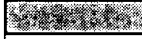 & 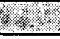 & & & \\
\hline IV 期 & 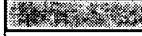 & Whe. & & & \\
\hline V 期 & 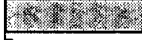 & IXy & & & \\
\hline & 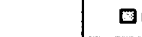 & 口L & mp & $\boldsymbol{D P}_{\mathrm{P}}$ & \\
\hline
\end{tabular}

図 9 一体型の親世代居室領域の推移

二つの型でどの期も $86 \%$ 以上を占め、年次が下がるにつ れてこの割合が変化するような傾向は、特に認められな かった（图 9）。

同居形態の一体型では、親世代の居室は独立領域型が 半数以上を占めている。0期においては隠居部屋の離れ に近い形態であり、時期が下がれば独立性を高めるため、 分離する方向に動いている。公室領域には家族がくつろ ぐ場としての居間、茶の間、ダイニングキッチンと接客 の場としての座敷、応接室がある。当然のことながら、 これらは同じ公室でも、意味あいが全く異なる。

公室領域の居間は親世代と子世代の接点となり、座敷 応接室などの接客空間は対外的な姿勢を示す場となる。 公室領域接続のうち、 L, D，Kなどに接続するものが、 $72.2 \%$ 、座敷などに接続が $27.8 \%$ である。私室領域に接 続する型は、他世代とのかかわりの度合を示す。親世代 の居室が他の私室と同領域にある型は、私室領域が 1 ソ ーンにまとめらられることが多く、その場合 1 階は公室 領域、2 階は私室領域とする形式が多い。また主寝室と 接続する型、孫の子供室と同領域にある型も見られる。

\section{2 経路}

居住形態で中高龄者の独立度を見る時、専用玄関の有 無が一つの指標となる。同様の理由で、一体型の場合に は玄関から親世代専用室に到る経路が、親世代の独立度 を考慮する際の手がかりになると思われる。経路につい ては表 8に示す4パターンを考えた。全体的に見ると、 独立領域型は玄関より直接出入り可能な平面型が $45 \%$ 、 奥まった位置の平面型が $28.5 \%$ 、他は各々 $13 \%$ を占めて いる。公室領域接続型では、公室経由の平面型が $50 \%$ 、 玄関より直接出入り可能な平面型 $30.4 \%$ 、奥まった位置 の平面型が $17.2 \%$ となっており、他の私室と同領域にあ

表 8 経路パターン

\begin{tabular}{|c|l|}
\hline 型 & \multicolumn{1}{|c|}{ 内容 } \\
\hline $\mathrm{A}$ & 公室を経由する \\
\hline $\mathrm{B}$ & $\begin{array}{l}\text { 公宔を経由せず、廊下や階段などから居室に出入りす } \\
\text { る }\end{array}$ \\
\hline $\mathrm{AB}$ & 公室を経由し、さらに階段などを通る \\
\hline $\mathrm{E}$ & 玄関と直接繁がっている型 \\
\hline
\end{tabular}

る型は、すべて私室である故、奥まった位置の平面型が 多くなる傾向にあるようである。

居間を中心として各私室が配置された公私同一領域の 平面型では、公室経由の事例が圧倒的に多い。先にも述 ベたが、一体型における親世代の領域としては、独立領 域型と公室領域接続型の二つで、86\%と大部分を占める。 その代表的な独立領域型、公室領域接続型について各々 の経路の推移を図 10に示す。独立領域型については0期 は従来の様式の平面型が多く親世代の居室も、離れに近 い奥まった位置の平面型が $62.5 \%$ を占める。I 期は戦後 の規制された延床面積の影響と、戦後の合理的ともいえ る平面型が多く、公室経由が $44.4 \%$ を占める。公室経由 型はII期以降减少して、III期には5.2\%になる。一方、玄 関より面接出入り可能な平面型は0 期より漸次増加し、 $\mathrm{V}$ 期には半分以上を占める。親世代の居室が独立した領 域の平面型であっても、位置、経路が変化していること が認められた。公室䫅域接続型はすべての期で公室経由 の比率が高く、II期は特に高率を示しているが、ほぼ42 〜 $50 \%$ を推移している。玄関より直接出入り可能な平面 型も II 期以降少しずつ增加して30〜42\%を占めている。
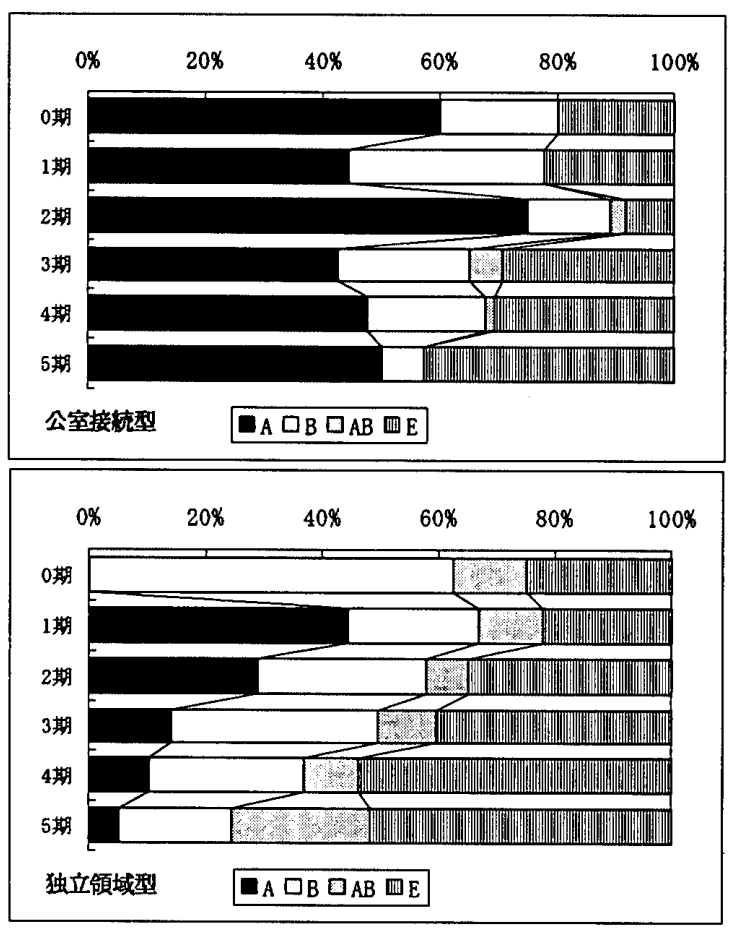

図 10 一体型の親世帯領域への経路の変化

\section{8}

（1）同居形態は、依然として一体型が主流であるが、 確実に共用型、分離型へと分離する傾向が認められる。

しかし、V期でも一体型は60\%前後を占め、単純に一 体型が减少し、共用型あるいは分離型へ移行するという 
ことではなく、今後この 3 つの型が共存していくものと 思われる。

（2）一体型、共用型、ともに時代の経過とともに、親 世代の専有領域の独立度が上がる傾向が顕著に認められ る。

一体型では、親世代の領域が専有化し、玄関からの出 入りがしやすい位置へと移行する。

共用型の共用形式は玄関、浴室共用例が最も多い。次 に親世代台所所有の形態が多く、一体型に近い共用型事 例の占める割合も高い。しかし、共用型でも親世代の独 立度は高まっている。

（3）分離型が増えているが、このことは、分離型がさ らに增え、最終的には親子が二世帯に完全に分離する方 向に向かうことを意味しない。

分離型では、完全に分離する形態が減り、二世帯がど こかで繋がりを持つ形が確実に増えている。即かず、離 れずの形態に収斂していくことがうかがえる。つまり三 世代が同居するといらわが国の伝統的な居住形式は、今 後も主要な形として残っていくだろう。

(4) 一体型、共用型、分離型のどの形態を選択するか は、家族構成や、家族のライフステージによるところが 大きいものと思われる。同居経緯、同居時期などが影響 するものと思われるが、この研究だけではその要因を特 定できない。

本論文は、三世代同居に関する、放送大学本間研究室 と、（株）長谷工総合研究所との一連の共同研究の一部 である。

脚注

i 同一敖地内別棟までを含める

ii 最初の子どもの結婚から、親世代の双方が死亡するまでの期間

iii 松本暢子 : 既成市街地の高跉者居住に関する研究 (1)、日本 建築学会計画系論文報告集 №. 345, pp. 131 139, 1984. 11

同 (2) 、No. 354, pp. 61 $69,1985.8$

同 (3)、No. 377, pp., 1987.7

iv 清水安子:二世帯住宅における平面構成の成り立ち、日本建築学 会計画系論文報告集 No. 334, pp. 165 173, 1983. 12

v 小川正光、小川裕子: 高齔者を含む世带における住宅事情の地方 類型、日本建築学会計画系論文報告集 No. 403, pp. 115～123， 1989.9

vi 本間博文他 : 三世代同居家族の住生活に関する研究一第三報 家族生活の型分類 日本建築学会学術講演梗概集（九州）5126， 1989. 10

vii 中里和彦、本間博文他、住生活の型分類に関する研究一その 2 日本建築学会学術捧演梗概集（関東）5129, 1993.09
そその他参考とした文献

1) 高阪㴚次: 高粭者の同別居の現状と志向に関する研究、日本建筑 学会計画系論文報告集 No. 409, pp. 85 94, 1990.3

2) 西身芳子：中高龄者世带における住宅所有関保別家族居住特性、 日本建築学会計画系論文報告集 No. 421, pp. 95 102, 1991.3

3) 沖田富美子：親子二世帯同居の住まい方、日本建築学会学術講演 梗概集（九州）5109、1981.9

4)佐藤平：三世代同居住宅の建築計画に関する研究、日本建築学会 学術講演梗概集（関東） 51001984.10

5)川手光太：老人を含む家族パターンと居住水泽 日本建策学会学 術講演梗概集（近畿）8085 1987.10 など

（1995年 1 月 10 日原稿受理， 1995 年 8 月 2 日採用決定） 